\title{
Poprawa przeżyć chorych na nowotwory złośliwe w Polsce. Analiza przeżyć pacjentów zdiagnozowanych w latach 2003-2005
}

\author{
Urszula Wojciechowska, Joanna Didkowska
}

Wstęp. Populacyjne wskaźniki przeżyć są narzędziem pozwalającym ocenić skuteczność leczenia chorób nowotworowych. Dysponując danymi dotyczącymi różnych okresów, można ocenić zmiany w skuteczności leczenia wynikające zarówno z wprowadzenia nowych metod leczenia, jak i wszystkich działań z zakresu profilaktyki zdrowotnej. Przedstawione wskaźniki przeżyć oszacowano dla chorych zdiagnozowanych w Polsce w latach 2003-2005. Nowe dane zostały porównane ze wskaźnikami obliczonymi dla okresu 2000-2002.

Materiał i metody. Analizę przeżyć przeprowadzono w oparciu o zbiór zachorowań na nowotwory, zgłoszonych do Krajowego Rejestru Nowotworów. Do analizy włączono 341241 pacjentów w wieku 15-99 lat, u których nowotwór złośliwy rozpoznano w latach 2003-2005. Oszacowane wskaźniki przeżyć względnych wyliczone zostały metodą Hakulinena przy użyciu programu SURV3. Analizę wykonano dla 17 najczęstszych nowotworów u mężczyzn i kobiet. Wyniki zostały porównane ze wskaźnikami oszacowanymi dla pacjentów zdiagnozowanych w latach 2000-2002 oraz ze wskaźnikami zbliżonych okresów diagnozy, przedstawionymi przez rejestry wojewódzkie, które takie wskaźniki opublikowały. Wyniki bieżącej analizy dla Polski nie zostały porównane ze wskaźnikami europejskimi, ponieważ wskaźniki przeżyć dla chorych zdiagnozowanych po 2003 roku przygotowywane przez EUROCARE-5 nie zostały jeszcze opublikowane.

Wyniki. Wskaźnik 5-letnich przeżyć względnych oszacowany dla chorych na nowotwory ogółem (bez względu na płeć), zdiagnozowanych w latach 2003-2005 w Polsce, wynosił 45,5\%. Średni wiek pacjenta w chwili diagnozy wynosił 63 lata, a odsetek utraconych w wyniku choroby lat życia szacuje się na blisko 79\%. Wartość wskaźników przeżycia chorych na nowotwory ogółem znacząco różniła się w zależności od płci. Ich wartość była niższa u mężczyzn — 37,3\% niż u kobiet — 53,5\%. Wśród włączonych do analizy nowotworów najwyższe wskaźniki przeżyć w populacji mężczyzn zanotowano u chorych na nowotwory: jądra (87,6\%), chłoniaka Hodgkina (77,8\%), gruczołu krokowego (76,4\%) oraz pęcherza moczowego $(61,4 \%)$. Najniższe wskaźniki zaobserwowano w przypadku nowotworów: przełyku $(7,1 \%)$, płuca $(11,9 \%)$ oraz żołądka $(16,4 \%)$. W populacji kobiet najwyższe wskaźniki przeżyć zarejestrowano u chorych z nowotworami: tarczycy (93,3\%), chłoniakiem Hodgkina (82,7\%), trzonu macicy (78,7\%), piersi (77,2\%) oraz czerniakiem skóry (71,3\%). Najgorsze rokowania zanotowano u pacjentek z nowotworami: płuca (16,9\%) i żołądka (19,8\%). W porównaniu z poprzednim analizowanym okresem (lata 2000-2002) nastąpiła poprawa 5-letnich przeżyć u chorych zdiagnozowanych w latach 2003-2005: u mężczyzn o 4,4 punkty procentowe, a u kobiet o 2,3 punkty procentowe. Porównując długość przeżycia chorych mieszkających w trzech włączonych do analizy województwach, obserwuje się zróżnicowanie w zależności od lokalizacji nowotworu: o \pm 4 punkty procentowe u mężczyzn oraz nieco większe u kobiet - o około \pm 6 punktów procentowych.

Podsumowanie. Analiza przeżyć chorych na choroby onkologiczne w Polsce, zdiagnozowanych w latach 2003-2005, wykazała wzrost 5-letnich wskaźników przeżyć w porównaniu z obserwowanymi w latach poprzednich. Podobne korzystne zmiany obserwuje się we wszystkich województwach, które systematycznie liczą i analizują wskaźniki przeżyć. Wzrost przeżywalności chorych nowotworowych wynika prawdopodobnie z wielu przyczyn, z których najważniejszymi wydają się być poprawa świadomości zdrowotnej pacjentów i związana z tym „czujność epidemiologiczna" skutkująca wcześniejszym zgłaszaniem się do lekarza oraz stopniowa poprawa leczenia wynikająca z ogólnej poprawy standardów leczenia.

Zakład Epidemiologii i Prewencji Nowotworów

Centrum Onkologii — Instytut im. Marii Skłodowskiej-Curie w Warszawie 


\section{Improvement in survival of cancer patients in Poland: analysis of survival of patients diagnosed 2003-2005}

Introduction. Population-based survival rates are tools for evaluating the effectiveness of cancer treatment. The observation of changes in rates over time can assess the changes in the effectiveness of treatment resulting from both the introduction of new types of treatment, as well the activities in the field of health prevention programs. The anal ysis shows the survival rates for patients diagnosed in Poland 2003-2005 and this new data was compared with the rates calculated for the period 2000-2002.

Material and methods. The survival analysis was based on a set of new cases of cancer in the Polish National Cancer Registry. The analysis included 341,241 patients aged 15-99 years, who were diagnosed with cancer 2003-2005. The analysis excluded cases of cancer in children aged 0-14 years, cases registered on the basis of a death certificate or autopsy (DCO) only, skin cancers other than melanoma (C44) and cancers in situ (D00-D09). The estimated 5-year relative survival rates were calculated using the Hakulinen method by the SURV3 programme. The life tables for the Polish population used in the analysis were provided by the Central Statistical Office in Warsaw. The analysis was performed for the 17 most common cancers in men and women. The results were compared with the rates estimated for patients diagnosed in years 2000-2002 and the survival rates estimated for similar periods of diagnosis by selected regional registries. The results of the current analysis for Poland have not been compared with the European indicators because the survival rates for patients diagnosed after 2003 have not yet been published (EUROCARE-5).

Results. The estimated 5-year relative survival rates for patients with all cancers who were diagnosed in 2003-2005 in Poland was $45.5 \%$. The average age of patients at diagnosis was 63 years and the percentage of lost years of life is estimated at nearly $79 \%$. The 5 -year survival rates of cancer patients significantly differed between the sexes. Their value was lower in males: $37.3 \%$ compared with $53.5 \%$ for females. The highest rates in the males were in cancers of the testis $(87.6 \%)$, thyroid gland (84.4\%), Hodgkin's lymphoma (77.8\%), prostate (76.4\%), and bladder (61.4\%). The lowest rates were in cancers of the oesophagus (7.1\%), lung (11.9\%) and stomach (16.4\%). In women the highest rates were estimated for cancers of the thyroid gland (93.3\%), Hodgkin's lymphoma (82.7\%), uterus (78.7\%), breast (77.2\%) and melanoma (71.3\%). The worst prognosis was in patients with cancers of the lung (16.9\%) and stomach (19.8\%). In comparison to the previously analyzed period (2000-2002) an improvement in life expectancy was noted among men by 4.4 percentage points and in women by 2.3 percentage points. Comparing the 5 -year survival rates of patients living in the three different voivodeships, which were part of the study, the observed variation depending on the location of the tumour with \pm 4 percentage points for men and \pm 6 percentage points for women.

Summary. The analysis of survival of patients diagnosed with cancers in Poland in 2003-2005 showed an increase in survival compared to that observed in previous years. Similar beneficial changes were observed in all regions which estimated survival rates. The increase in survival of cancer patients is due to many reasons, the most important seem to be improved health literacy of patients associated with "epidemiological vigilance", which translates to earlier diagnosis of cancers and a gradual improvement resulting from improved standards of treatment.

NOWOTWORY Journal of Oncology 2013; 63, 4: 279-285

Słowa kluczowe: nowotwory, przeżycia, rejestr nowotworów

Key words: cancer survival, population-based cancer registries

\section{Wstęp}

Populacyjne wskaźniki przeżyć są narzędziem pozwalającym ocenić skuteczność leczenia chorób nowotworowych. Podstawowym źródłem danych pozwalającym na oszacowanie wskaźników są rejestry nowotworowe systematycznie gromadzące dane o nowych zachorowaniach na nowotwory występujących w populacji objętej rejestrem. Wskaźniki przeżyć można szacować również dla grupy pacjentów pod kątem miejsca leczenia (np. szpital) lub wyselekcjonowanych pacjentów poddanych konkretnej metodzie leczenia. Wartości tych wskaźników zwykle różnią się od wskaźników populacyjnych, na które wpływ ma wiele elementów związanych z chorobą, takich jak: typ nowotworu, zaawansowanie choroby w momencie rozpoznania, czas rozpoczęcia leczenia, zastosowane metody leczenia, miejsce leczenia. $\mathrm{Na}$ wartość wskaźników ma również wpływ jakość i kompletność danych włączonych do analizy.

W Polsce rejestracja nowotworów złośliwych ma ponad 50-letnią historię. Przez wiele lat ograniczony dostęp do informacji o dacie zgonu pacjenta uniemożliwiał ocenę przeżyć w skali populacyjnej. Poprawa jakości i kompletności danych w ostatnich latach, a przede wszystkim możliwość 
systematycznego uzupełniania danych w rejestrach o datę zgonu, pozwoliły na analizę przeżyć dla populacji Polski. Pierwszą taką analizę wykonano dla pacjentów zarejestrowanych w latach 2000-2002. Bieżąca analiza pozwoliła na ocenę wskaźników 5-letnich przeżyć dla osób, u których zdiagnozowano nowotwór w latach 2003-2005 oraz porównanie ich z poprzednim okresem. Porównanie wskaźników publikowanych przez rejestry wojewódzkie, które dokonały analizy przeżyć dla podobnego przedziału lat diagnozy, pozwoliło na wstępną ocenę zróżnicowania regionalnego w długości życia pacjentów onkologicznych w Polsce.

\section{Materiał i metody}

Analizę przeżyć przeprowadzono w oparciu o zbiór zachorowań na nowotwory zarejestrowane w latach 2003-2005 i zgromadzone w bazie danych będącej połączeniem zbiorów 16 wojewódzkich rejestrów nowotworowych. Początkowy zbiór liczył 391037 przypadków. Ze zbioru wyłączone zostały zachorowania u dzieci w wieku 0-14 lat, zachorowania zarejestrowane wyłącznie na podstawie aktu zgonu lub sekcji zwłok (DCO — death certificat only), zachorowania na nowotwory skóry inne niż czerniak (C44) oraz zachorowania na nowotwory in situ (D00-D09). Nowotwory kodowane były zgodnie z obowiązującą w Polsce Międzynarodową Statystyczną Klasyfikacją Chorób i Problemów Zdrowotnych (rewizja X). Do analizy włączono 341241 pacjentów w wieku 15-99 lat ze zdiagnozowanymi nowotworami złośliwymi z zakresu C00-C96 (bez nowotworów skóry - C44).

Pacjenci, u których data zgonu nie została ustalona przez wojewódzkie rejestry nowotworowe na podstawie aktualnej informacji zgłoszonej do rejestru, zostali jednorazowo (w grudniu 2010 roku) sprawdzeni pod kątem vital status w Departamencie Ewidencji Państwowej i Teleinformatyki MSW na podstawie zapytania Krajowego Rejestru Nowotworów.

Oszacowane wskaźniki 5-letnich przeżyć względnych wyliczone zostały metodą Hakulinena przy użyciu programu SURV3 [1]. Program szacuje również odsetek utraconych lat życia chorego, który jest różnicą pomiędzy oczekiwaną długością trwania życia a przeciętną długością trwania życia w zdrowiu, wyrażoną w procentach oczekiwanej długości trwania życia. Wykorzystane w analizie tablice trwania życia dla populacji polskiej w latach 2003-2010 zostały udostępnione przez Główny Urząd Statystyczny w Warszawie.

Analizę wykonano dla nowotworów ogółem oraz 17 najczęstszych nowotworów w populacji mężczyzn i kobiet. Wyniki zostały porównane ze wskaźnikami oszacowanymi dla pacjentów zdiagnozowanych w latach 2000-2002 [2]. W celu pokazania zróżnicowania regionalnego w przeżyciach chorych onkologicznych najnowsze dane dla Polski porównano ze wskaźnikami zbliżonych okresów diagnozy, przedstawionymi przez rejestry wojewódzkie: dolnośląski, podkarpacki oraz śląski. Wskaźniki przeżyć w wojewódz- twach obliczone zostały z wykorzystaniem tej samej metody analizy (Hakulinena) [3-5].

Wyniki bieżącej analizy dla Polski nie zostały porównane ze wskaźnikami europejskimi, ponieważ wskaźniki przeżyć dla chorych zdiagnozowanych po 2003 roku przygotowywane przez EUROCARE-5 nie zostały jeszcze opublikowane.

\section{Wyniki}

Wskaźnik 5-letnich przeżyć względnych oszacowany dla chorych na nowotwory ogółem (bez podziału na płeć), zdiagnozowanych w latach 2003-2005, w Polsce wynosił 45,5\%. Średni wiek pacjenta w chwili diagnozy wynosił 64 lata, a odsetek utraconych w wyniku choroby lat życia szacuje się na blisko 79\% (tab. I).

Wartość 5-letnich wskaźników przeżyć chorych na nowotwory ogółem znacząco różniła się w zależności od płci. Ich wartość była niższa u mężczyzn (37,3\%) niż u kobiet (53,5\%) (tab. Il). Znacząco niższy wskaźnik w populacji mężczyzn wynika z blisko 30\% udziału nowotworów o złym rokowania (przełyk, wątroba, pęcherzyk żółciowy, trzustka, płuco) w strukturze zachorowań [6]. W populacji kobiet ponad 30\% zachorowań to nowotwory o dobrym rokowaniu (tarczyca, trzon macicy, pierś), poddające się skutecznemu leczeniu, a nowotwory o najgorszych prognozach (pęcherzyk żółciowy, przełyk, wątroba, trzustka, płuco) stanowią około 12\% zachorowań [6].

W populacji mężczyzn najwyższe wskaźniki przeżyć zanotowano u chorych na nowotwory:jądra $(87,6 \%)$, tarczycy $(84,4 \%)$, chłoniaka Hodgkina (77,8\%), gruczołu krokowego $(76,4 \%)$ oraz pęcherza moczowego $(61,4 \%)$. Najniższe wskaźniki zaobserwowano w przypadku nowotworów: przełyku (7,1\%), płuca (11,9\%) oraz żołądka (16,4\%) (tab. II, ryc. 1). Przeciętny wiek mężczyzny, u którego zdiagnozowano nowotwór, wynosił 64 lata. Wśród pacjentów najniższa średnia wieku w momencie rozpoznania obserwowana była u chorych na raka jądra (34 lata), chłoniaka Hodgina (42 lata) oraz nowotwory tarczycy (54 lata). Wśród pacjentów o najwyższej średniej wieku dominowały zachorowania na raka gruczołu krokowego (70 lat) oraz pęcherza moczowego i jelita grubego (67 lat) (tab. II).

W populacji kobiet najwyższe wskaźniki przeżyć zarejestrowano u chorych z nowotworami: tarczycy (93,3\%), chłoniakiem Hodgkina (82,7\%), trzonu macicy $(78,7 \%)$, piersi $(77,2 \%)$ oraz czerniakiem skóry $(71,3 \%)$. Najgorsze rokowania zanotowano u pacjentek z nowotworami: płuca $(16,9 \%)$ i żołądka (19,8\%) (tab. Il, ryc. 1).

Przeciętny wiek kobiet, u których wykryto nowotwór, wynosił 62 lata. Wśród pacjentek najniższa średnia wieku w chwili diagnozy obserwowana była u chorych na chłoniaka Hodgkina (37 lata), nowotwory tarczycy (52 lata) oraz raka szyjki macicy (55 lat). Wśród pacjentek o najwyższej średniej wieku dominowały zachorowania na raka pęcherza moczowego, jelita grubego i żołądka (68 lat) (tab. II). 
Tabela I. Wskaźniki 5-letnich przeżyć względnych w Polsce u pacjentów zdiagnozowanych w latach 2003-2005 (mężczyźni i kobiety razem)

\begin{tabular}{|c|c|c|c|c|c|c|}
\hline Przyczyna & ICD-10 & $\begin{array}{c}\text { Liczba } \\
\text { przypadków }\end{array}$ & $\begin{array}{l}\text { 5-letnie przeżycie } \\
\text { względne (\%) }\end{array}$ & $95 \% \mathrm{Cl}$ & $\begin{array}{l}\text { Średnia wieku } \\
\text { zachorowania }\end{array}$ & $\begin{array}{l}\text { Odsetek utraconych } \\
\text { oczekiwanych lat życia }\end{array}$ \\
\hline Ogółem & $\mathrm{C} 00-\mathrm{C} 96$ & 341241 & 45,5 & $45,3-45,7$ & 63 & $79,1 \%$ \\
\hline Przełyk & $\mathrm{C} 15$ & 3723 & 8,3 & $7,3-9,3$ & 64 & $92,1 \%$ \\
\hline Żołądek & $\mathrm{C} 16$ & 15432 & 17,6 & $16,9-18,3$ & 67 & $87,5 \%$ \\
\hline Jelito grube & C81-C21 & 40689 & 48,3 & $47,7-48,9$ & 67 & $73,9 \%$ \\
\hline Krtań & C32 & 7707 & 52,3 & $50,92-53,6$ & 61 & $75,5 \%$ \\
\hline Płuco & C33-C34 & 59250 & 13,1 & $12,8-13,4$ & 65 & $89,5 \%$ \\
\hline Czerniak skóry & $\mathrm{C} 43$ & 6532 & 64,7 & $63,4-66,1$ & 58 & $76,0 \%$ \\
\hline Nerka & C64-C65 & 12012 & 57,8 & $56,7-58,9$ & 64 & $73,7 \%$ \\
\hline Pęcherz moczowy & C67 & 16352 & 62,2 & $61,2-63,2$ & 67 & $67,4 \%$ \\
\hline Mózg & C71 & 7183 & 26,0 & $24,9-27,2$ & 57 & $88,8 \%$ \\
\hline Tarczyca & $\mathrm{C} 73$ & 5268 & 91,8 & $90,8-92,9$ & 52 & $74,5 \%$ \\
\hline $\begin{array}{l}\text { Chłoniak } \\
\text { Hodgkina }\end{array}$ & $\mathrm{C} 81$ & 2469 & 80,2 & $78,4-82,0$ & 40 & $82,3 \%$ \\
\hline $\begin{array}{l}\text { Chłoniaki } \\
\text { nieziarnicze }\end{array}$ & C82-C85 & 6986 & 49,1 & $47,7-50,5$ & 61 & $79,3 \%$ \\
\hline $\begin{array}{l}\text { Białaczka } \\
\text { limfatyczna }\end{array}$ & C91 & 4066 & 52,1 & $50,2-54,0$ & 64 & $76,1 \%$ \\
\hline Białaczka szpikowa & $\mathrm{C} 92$ & 3217 & 25,7 & $24,0-27,4$ & 61 & $87,9 \%$ \\
\hline Białaczki & C91-C95 & 7804 & 39,9 & $38,6-41,1$ & 63 & $81,8 \%$ \\
\hline
\end{tabular}

W porównaniu do poprzedniego analizowanego okresu (lata 2000-2002) zauważono poprawę wskaźników 5-letnich przeżyć u chorych zdiagnozowanych w latach 2003-2005: u mężczyzn o 4,4 punkty procentowe, a u kobiet o 2,3 punkty procentowe. W populacji mężczyzn największy wzrost zaobserwowano u chorych na raka gruczołu krokowego (ponad 11 punktów procentowych), chłoniaka Hodgkina i białaczki (5-7 punktów procentowych), jelita grubego i pęcherza moczowego (ok. 4 punkty procentowe). Nie zaobserwowano zmian w przeżywalności chorych na raka krtani i jądra. W populacji kobiet największa zmiana nastąpiła w przeżyciach chorych na nowotwory nerki, czerniaka skóry, białaczki, chłoniaki, raka pęcherza moczowego i jelita grubego (około 4-6 punktów procentowych). Najmniejsze zmiany nastąpiły u chorych na raka szyjki macicy, nowotwory mózgu i jajnika (około 0,5 punktu procentowego) (ryc. 2).

Wskaźniki przeżyć u kobiet są wyższe niż u mężczyzn o 1 do 15 punktów procentowych. Największa różnica występuje w przypadku czerniaka skóry (15 punktów procentowych), nowotworów tarczycy (9 punktów procentowych) oraz nerki (8 punktów procentowych). Najmniejszą różnicę w długości przeżyć (1-2 punkty procentowe) zaobserwowano u chorych na białaczki i raka jelita grubego (tab. I, II, ryc. 1).

Porównując wskaźniki 5-letnich przeżyć chorych mieszkających w trzech włączonych do analizy województwach obserwuje się zróżnicowanie w zależności od lokalizacji nowotworu: $\mathrm{o} \pm 4$ punkty procentowe u mężczyzn oraz nieco więcej, o około \pm 6 punktów procentowych u kobiet. Wyjątek stanowi województwo podkarpackie, w którym oszacowany wskaźnik 5-letnich przeżyć u mężczyzn z nowotworem prostaty jest niższy o 9 punktów procentowych w porównaniu ze wskaźnikiem ogólnopolskim, a u kobiet z rakiem szyjki macicy jest wyższy o 11 punktów procentowych od wskaźnika ogólnopolskiego (ryc. 2).

\section{Omówienie}

Na czas przeżycia pacjenta chorego na nowotwór ma wpływ wiele czynników. Najważniejsze z nich to: typ nowotworu, stadium zaawansowania nowotworu w momencie rozpoznania, wiek pacjenta, szybkość podjęcia leczenia, zastosowane metody oraz ich skuteczność, ośrodek, w którym pacjent jest leczony, choroby towarzyszące, efekty uboczne leczenia oraz szereg czynników zewnętrznych wynikających z lokalnej organizacji opieki zdrowia [7]. Na ogólne wskaźniki przeżyć ma również wpływ częstość występowania nowotworów o dobrym i złym rokowaniu. Duży udział tych ostatnich może znacząco obniżyć wartość wskaźników ogółem.

Analiza przeżyć chorych na choroby onkologiczne w Polsce zdiagnozowanych w latach 2003-2005, wykazała wzrost czasu przeżycia w porównaniu z obserwowanym w latach poprzednich, tj. do 37,3\% u mężczyzn i 53,3\% u kobiet. Wzrost wskaźników 5-letnich przeżyć u mężczyzn o 4,4 punkty procentowe jest prawdopodobnie wynikiem systematycznego spadku zapadalności na raka płuca u mężczyzn oraz zmniejszający się jego udział w strukturze 
Tabela II. Wskaźniki 5-letnich przeżyć względnych w Polsce u pacjentów zdiagnozowanych w latach 2003-2005 w zależności od płci

\begin{tabular}{|c|c|c|c|c|c|c|}
\hline Przyczyna & ICD-10 & $\begin{array}{c}\text { Liczba } \\
\text { przypadków }\end{array}$ & $\begin{array}{l}\text { 5-letnie przeżycie } \\
\text { względne (\%) }\end{array}$ & $95 \% \mathrm{Cl}$ & $\begin{array}{l}\text { Średnia wieku } \\
\text { zachorowania }\end{array}$ & $\begin{array}{l}\text { Odsetek utraconych } \\
\text { oczekiwanych lat życia }\end{array}$ \\
\hline \multicolumn{7}{|c|}{ Mężczyźni } \\
\hline Ogółem & $\mathrm{C} 00-\mathrm{C} 96$ & 176706 & 37,3 & $37,0-37,6$ & 64 & $79,6 \%$ \\
\hline Przełyk & $\mathrm{C} 15$ & 2957 & 7,1 & $6,1-8,2$ & 63 & $92,4 \%$ \\
\hline Żołądek & $\mathrm{C} 16$ & 9967 & 16,4 & $15,5-17,2$ & 66 & $87,4 \%$ \\
\hline Jelito grube & $\mathrm{C} 81-\mathrm{C} 21$ & 21998 & 47,6 & $46,7-48,4$ & 67 & $72,1 \%$ \\
\hline Krtań & C32 & 6739 & 50,6 & $49,2-52,0$ & 61 & $75,2 \%$ \\
\hline Płuco & C33-C34 & 45465 & 11,9 & $11,5-12,2$ & 65 & $89,4 \%$ \\
\hline Czerniak skóry & $\mathrm{C} 43$ & 2971 & 56,4 & $54,3-58,6$ & 59 & $75,7 \%$ \\
\hline Gruczoł krokowy & C61 & 21007 & 76,4 & $75,5-77,3$ & 70 & $54,7 \%$ \\
\hline Jądro & C62 & 2567 & 87,6 & $86,1-89,0$ & 34 & $80,9 \%$ \\
\hline Nerka & C64-C65 & 7177 & 54,6 & $53,2-56,0$ & 63 & $73,7 \%$ \\
\hline Pęcherz moczowy & $\mathrm{C} 67$ & 12945 & 61,4 & $60,2-62,5$ & 67 & $66,3 \%$ \\
\hline Mózg & C71 & 3722 & 23,4 & $21,9-24,9$ & 56 & $89,0 \%$ \\
\hline Tarczyca & C71 & 925 & 84,4 & $81,1-87,6$ & 54 & $77,1 \%$ \\
\hline Chłoniak Hodgkina & C81 & 1277 & 77,8 & $75,1-80,5$ & 42 & $80,3 \%$ \\
\hline Chłoniaki nieziarnicze & C82-C85 & 3713 & 46,9 & $44,9-48,8$ & 60 & $79,4 \%$ \\
\hline Białaczka limfatyczna & C91 & 2393 & 50,5 & $48,0-53,0$ & 63 & $76,4 \%$ \\
\hline Białaczka szpikowa & C92 & 1677 & 25,0 & $22,6-27,4$ & 60 & $87,2 \%$ \\
\hline Białaczki & C91-C95 & 4347 & 39,4 & $37,7-41,2$ & 62 & $81,1 \%$ \\
\hline \multicolumn{7}{|c|}{ Kobiety } \\
\hline Ogółem & $\mathrm{C} 00-\mathrm{C} 96$ & 164535 & 53,5 & $53,2-53,7$ & 62 & $78,8 \%$ \\
\hline Żołądek & $\mathrm{C} 16$ & 5465 & 19,8 & $18,5-21,0$ & 68 & $87,6 \%$ \\
\hline Jelito grube & C81-C21 & 18691 & 49,1 & $48,3-50,0$ & 68 & $75,6 \%$ \\
\hline Płuco & C33-C34 & 13785 & 16,9 & $16,2-17,6$ & 64 & $89,7 \%$ \\
\hline Czerniak skóry & $\mathrm{C} 43$ & 3561 & 71,3 & $69,5-73,1$ & 58 & $76,3 \%$ \\
\hline Pierś & $\mathrm{C} 50$ & 38688 & 77,2 & $76,7-77,7$ & 59 & $73,3 \%$ \\
\hline Szyjka macicy & C53 & 10063 & 54,4 & $53,4-55,5$ & 55 & $81,7 \%$ \\
\hline Trzon macicy & C54 & 12876 & 78,7 & $77,8-79,6$ & 63 & $68,5 \%$ \\
\hline Jajnik & C56 & 10090 & 42,6 & $41,5-43,6$ & 59 & $83,1 \%$ \\
\hline Nerka & C64-C65 & 4835 & 62,4 & $60,8-64,0$ & 65 & $73,8 \%$ \\
\hline Pęcherz moczowy & C67 & 3407 & 65,1 & $63,1-67,1$ & 68 & $70,9 \%$ \\
\hline Mózg & C71 & 3461 & 28,7 & $27,0-30,3$ & 59 & $88,7 \%$ \\
\hline Tarczyca & $\mathrm{C} 73$ & 4343 & 93,3 & $92,3-94,4$ & 52 & $75,0 \%$ \\
\hline Chłoniak Hodgkina & C81 & 1192 & 82,7 & $80,3-85,1$ & 37 & $83,9 \%$ \\
\hline Chłoniaki nieziarnicze & $\mathrm{C} 82-\mathrm{C} 85$ & 3273 & 51,5 & $49,5-53,4$ & 63 & $79,2 \%$ \\
\hline Białaczka limfatyczna & C91 & 1673 & 54,4 & $51,5-57,3$ & 67 & $75,7 \%$ \\
\hline Białaczka szpikowa & C92 & 1540 & 26,4 & $23,9-28,8$ & 61 & $88,5 \%$ \\
\hline Białaczki & C91-C95 & 3457 & 40,3 & $38,5-42,2$ & 64 & $82,5 \%$ \\
\hline
\end{tabular}

zachorowań [8]. Największy przyrost odsetka pacjentów przeżywających 5 lat dotyczy mężczyzn z nowotworem prostaty (11,2 punktów procentowych). Trudno jednoznacznie wskazać przyczyny tak znacznego postępu. Wydaje się, że łatwość dostępu do badania poziomu PSA w surowicy krwi i coraz większa świadomość pacjentów (wymuszona choćby przez agresywną reklamę leków na przerost prostaty) oraz — być może - lepsza świadomość tego problemu u lekarzy pierwszego kontaktu spowodowały wcześniejsze zgłaszanie się pacjentów do lekarza onkologa.

Najmniejszy postęp w leczeniu odnotowano dla nowotworów jądra i krtani u mężczyzn oraz szyjki macicy i jajnika 


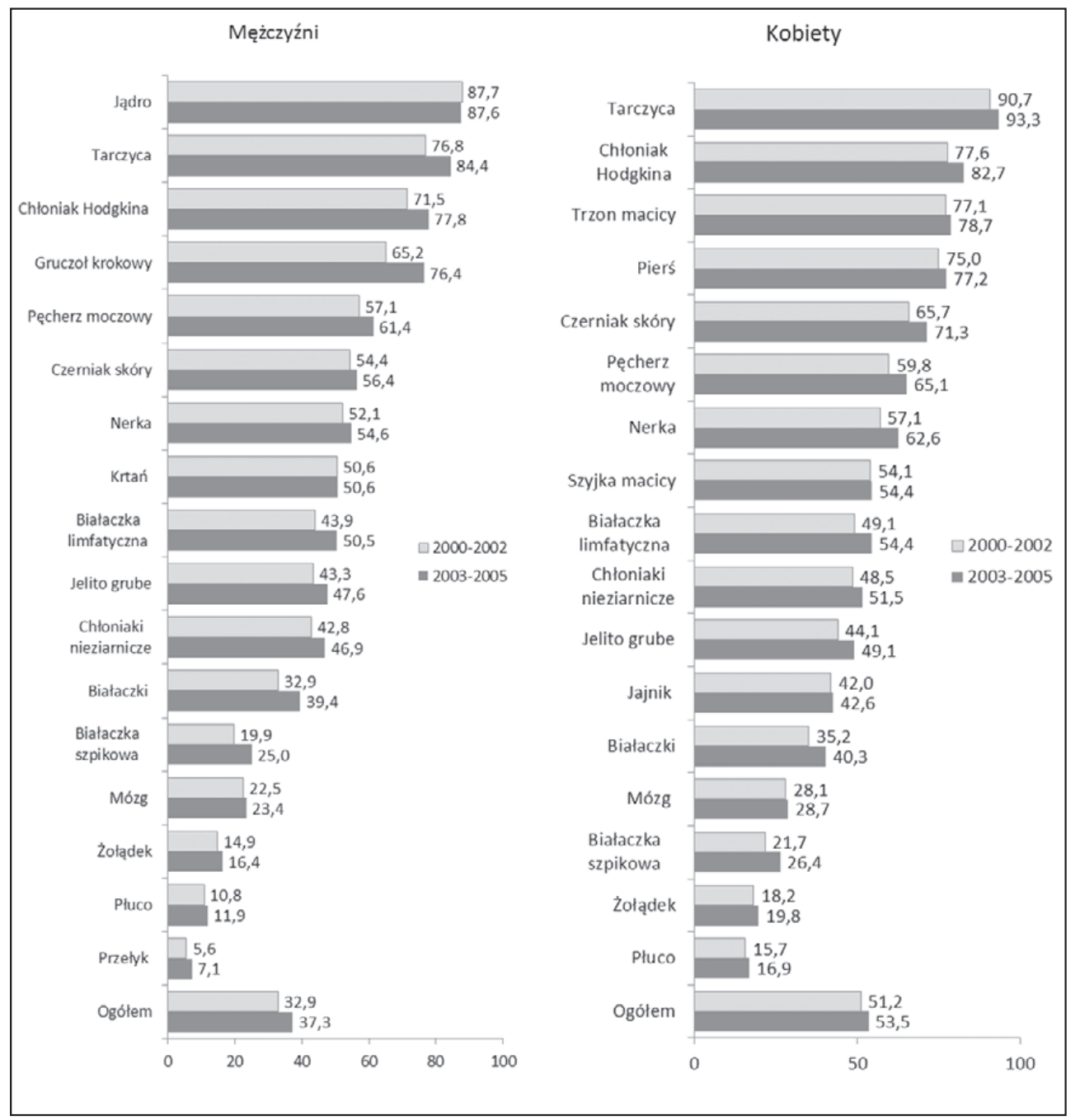

Rycina 1. Porównanie wskaźników 5-letnich przeżyć względnych w Polsce u pacjentów zdiagnozowanych w latach 2000-2002 i 2003-2005, według płci

u kobiet. W przypadku nowotworów jądra 5-letnie przeżycia stale wzrastają w krajach europejskich [9] i na tym tle brak postępu w polskiej populacji wymaga szczególnej uwagi, w tym przede wszystkim popularyzacji problemu wśród młodych mężczyzn.

W nowotworach krtani wskaźniki przeżyć 5-letnich w Europie w połowie lat 90 . wynosiły ponad 60\% [10], więc brak postępu w Polsce w przeżywalności chorych i wzrastająca różnica między wynikami osiąganymi w Europie i w Polsce wymaga pilnego wyjaśnienia.

Oszacowana zmiana w przeżywalności chorych na raka szyjki macicy w Polsce zakładała wzrost do około $57 \%$ na początku XXI wieku [10], jednak rzeczywiste wskaźniki przeżyć wskazują na brak postępu w leczeniu. Biorąc pod uwagę fakt, że w ciągu ostatnich dwóch dekad nie odnotowano przełomu w leczeniu raka szyjki macicy (dominującym sposobem leczenia jest nadal chirurgia), można zaryzykować stwierdzenie, iż pacjentki zgłaszają się tak późno, że interwencja lekarska jest mało skuteczna.
Przeżywalność chorych na raka jajnika w Polsce osiągnęła średni poziom obserwowany w innych krajach europejskich (37-42\%) i w USA (36-44\%) [11, 12].Wydaje się, że bez przełomu w metodach leczenia raka jajnika nie jest możliwy dalszy postęp w poprawie wskaźników przeżyć. Wczesne wykrycie raka jajnika jest zwykle dziełem przypadku, a programy skriningowe w tym zakresie nie spełniają oczekiwań [13].

Wzrost przeżywalności chorych nowotworowych wynika prawdopodobnie z wielu przyczyn, z których najważniejszymi wydają się być poprawa świadomości zdrowotnej pacjentów i związana z tym "czujność epidemiologiczna" skutkująca wcześniejszym zgłaszaniem się do lekarza oraz stopniowa poprawa leczenia wynikająca z ogólnej poprawy standardów leczenia.

Dr n. med. Urszula Wojciechowska

Zakład Epidemiologii i Prewencji Nowotworów

Centrum Onkologii — Instytut im. Marii Skłodowskiej-Curie

ul. Roentgena 5, 02-791 Warszawa

e-mail:wojciechowskau@coi.waw.pl 


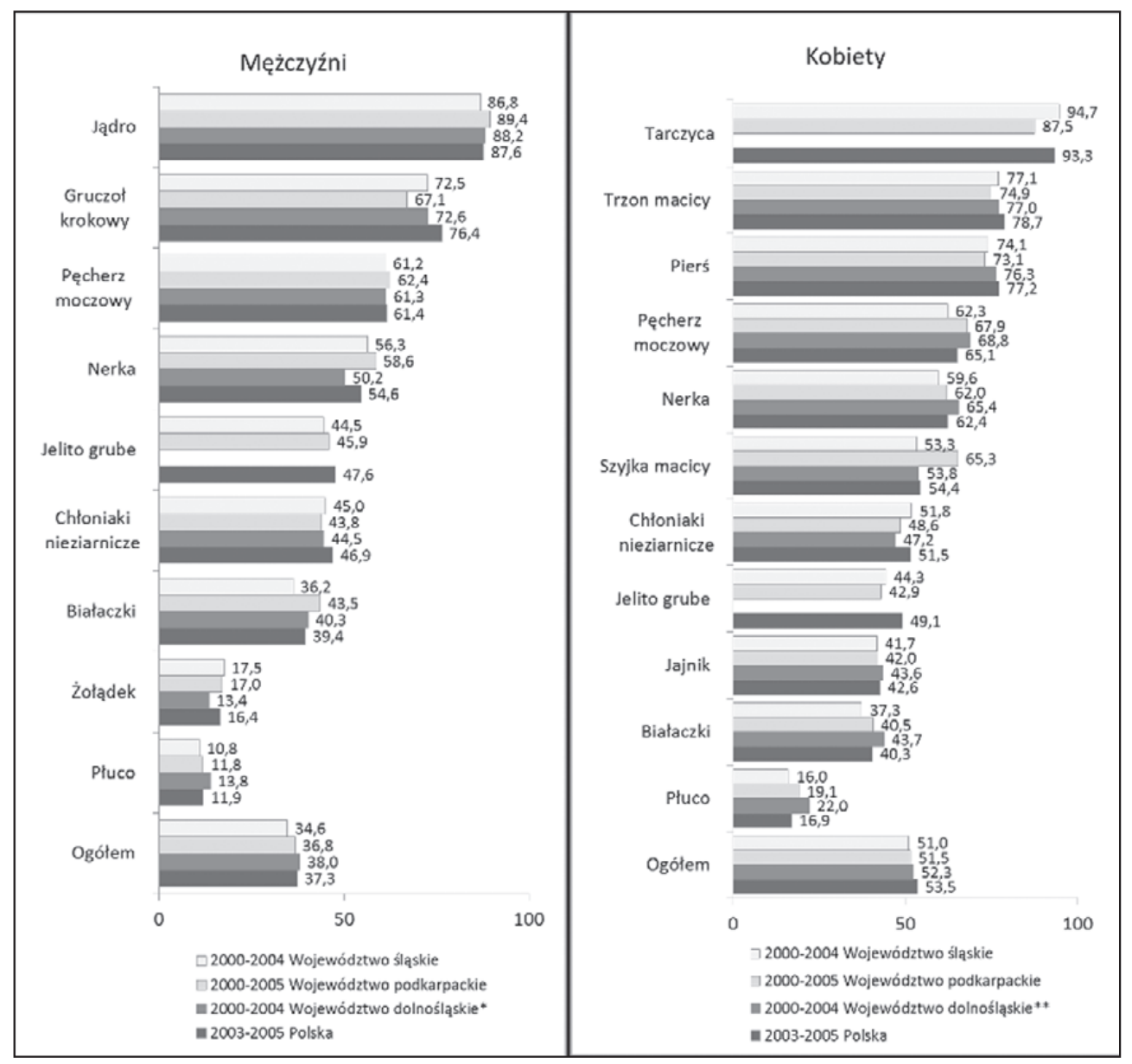

*Nie oszacowano wskaźników dla jelita grubego obejmujących zakres C18-C21

**Nie opublikowano wskaźnika przeżyć dla nowotworów tarczycy u kobiet

Rycina 2. Porównanie wskaźników 5-letnich przeżyć względnych w Polsce u pacjentów zdiagnozowanych w latach 2003-2005, ze wskaźnikami szacowanymi dla wybranych województw

Otrzymano: 14 stycznia 2013 r.

Przyjęto do druku: 21 stycznia 2013 r.

\section{Piśmiennictwo}

1. SURV3, informacje dostępne na stronie Fińskiego Rejestru Nowotworów (Finnish Cancer Registry). http://www.cancerregistry.fi/surv3/.

2. Wojciechowska U, Didkowska J, Zatoński W. Pięcioletnie przeżycia chorych na nowotwory złośliwe w Polsce. Nowotwory J Oncol 2010; $60 ; 122-128$.

3. Błaszczyk J, Jagas M, Hudziec P. Nowotwory złośliwe wwoj. dolnośląskim w 2010 roku. Wrocław: Dolnośląskie Centrum Onkologii, 2012.

4. Kwolek J. Przeżycia chorych na nowotwory złośliwe w woj. podkarpackim w latach 2000-2005. Rzeszów: Podkarpacki Urząd Wojewódzki w Rzeszowie, 2012.

5. BanasikT, Kołosza Z, Zemła B. Przeżycia chorych na nowotwory złośliwe w województwie śląskim w latach 2000-2007. Gliwice: Centrum Onkologii — Instytut, Oddział w Gliwicach, 2010.

6. Didkowska J, Wojciechowska U, Zatoński W. Nowotworyzłośliwe w Polsce w 2005 roku. Warszawa: Centrum Onkologii — Instytut, 2007.
7. Yu XQ, O'Connell DL, Gibberd RW, Smith DP i wsp. Estimating regional variation in cancer survival: a tool for improving cancer care. Cancer Causes Control 2004; 15: 611-618.

8. Wojciechowska U, Didkowska J, Zatoński W. Nowotworyzłośliwe w Polsce w 2008 roku. Warszawa: Centrum Onkologii — Instytut, 2009.

9. Testicular cancer in Europe and the USA: survival still rising among older patients. Ann Oncol 2013; 24: 508-513.

10. Karim-Kos HE, de Vries E, Soerjomataram I i wsp. Recent trends of cancer in Europe: A combined approach of incidence, survival and mortality for 17 cancer sites since the 1990s. Eur J Cancer 2008; 44: 1345-1389.

11. Buys SS, Partridge E, Black A i wsp. Effect of screening on ovarian cancer mortality: the Prostate, Lung, Colorectal and Ovarian (PLCO) Cancer Screening Randomized Controlled Trial. JAMA 2011; 305: 2295-303.

12. Howlader N, Noone AM, Krapcho Mi wsp. SEER Cancer Statistics Review, 1975-2009 (Vintage 2009 Populations), National Cancer Institute. Bethesda, MD, http://seer.cancer.gov/csr/1975_2009_pops09/, based on November 2011 SEER data submission, posted to the SEER web site, 2012.

13. Oberaigner W, Minicozzi P, Bielska-Lasota M i wsp. Survival for ovarian cancer in Europe: the across-country variation did not shrink in the past decade. Acta Oncol 2012; 51: 4414-53. 